\title{
The Evolutionary Dynamics of Biofuel Value Chains From Unipolar and Government-Driven to Multipolar Governance
}

\author{
Ponte, Stefano
}

Document Version

Accepted author manuscript

Published in:

Environment and Planning A

DOI:

$10.1068 / \mathrm{a} 46112$

Publication date:

2014

License

Unspecified

Citation for published version (APA):

Ponte, S. (2014). The Evolutionary Dynamics of Biofuel Value Chains: From Unipolar and Government-Driven to Multipolar Governance. Environment and Planning A, 46(2), 353-372. https://doi.org/10.1068/a46112

Link to publication in CBS Research Portal

\section{General rights}

Copyright and moral rights for the publications made accessible in the public portal are retained by the authors and/or other copyright owners and it is a condition of accessing publications that users recognise and abide by the legal requirements associated with these rights.

Take down policy

If you believe that this document breaches copyright please contact us (research.lib@cbs.dk) providing details, and we will remove access to the work immediately and investigate your claim. 


\section{The Evolutionary Dynamics of Biofuel Value Chains: From Unipolar and Government-Driven to Multipolar Governance Stefano Ponte}

Journal article (Post print version)

CITE: The Evolutionary Dynamics of Biofuel Value Chains: From Unipolar and Government-Driven to Multipolar Governance. / Ponte, Stefano. In: Environment and Planning A, Vol. 46, No. 2, २०14, p. 353-372.

DOI: 10.1068/a46112

Uploaded to Research@CBS: May २०17 


\title{
The evolutionary dynamics of biofuel value chains: From unipolar and government-driven to multipolar governance
}

\author{
Stefano Ponte \\ Department of Business and Politics, Copenhagen Business School, Steen Blichers \\ Vej 22, 2000 Frederiksberg, Denmark; sp.dbp@cbs.dk
}

\begin{abstract}
In this article, I propose to push the frontier of Global Value Chain governance analysis through the concept of 'polarity'. Much of the existing GVC literature has focused on 'unipolar' value chains, where one group of 'lead firms' inhabiting a specific function in a chain play a dominant role in governing it. Some scholars have explored the dynamics of governance in GVCs characterized as 'bipolar', where two sets of actors in different functional positions both drive the chain. I expand this direction further to suggest conceptualizing governance within a continuum between unipolarity and multipolarity. Empirically, I do so by examining the evolutionary dynamics of governance in biofuel value chains, with specific focus on the key regulatory and institutional features that facilitated their emergence and expansion. First, I examine the formation, evolution and governance of three national/regional value chains (in Brazil, the US and the EU); then, I provide evidence to support a trend towards the increasing but still partial formation of a global biofuel value chain and examine its governance traits.
\end{abstract}

Key words. Global Value Chains, governance, polarity, biofuels 


\section{Introduction}

This article examines the evolutionary dynamics of governance in biofuel value chains, with specific focus on the key regulatory and institutional features that facilitated their emergence and expansion. It aims at providing a historical trajectory of governance, at tracing the national (Brazil, US) and regional (EU) foundations of an increasingly global biofuel value chain, and at highlighting the complexity of constellation of actors engaged in its governance. In doing so, it attempts to partially address three relevant criticism of Global Value Chain (GVC) analysis: (1) that it often provides static accounts of governance; (2) that it does not sufficiently engage with the local, national and regional foundations of global industries; and (3) that by focusing on firm-to-firm relations, it does not properly examine the role that other actors play in GVC governance - such as governments, social movements, labour unions or NGOs.

The experience of the global biofuel value chain examined in this article suggests that industries are not simply established through entrepreneurship, competition and market mechanisms, but are also actively and heavily forged through the actions of governments. Since the 1990s, governments in Brazil, the US and the EU (the main biofuel producing and consuming countries/regions) have been heavily promoting biofuels and enacting 'value chain-forging' policies, often under pressure from industry and agricultural lobbies. These policies were justified in relation to climate change mitigation (especially in the EU), energy security (especially in the US) and farmer support and rural development (in Brazil, but also in the US and EU). The original allure of biofuels from a policy perspective was that they could be framed as 
being able to address climate change, energy security and rural development at once without fundamentally altering energy consumption practices. Until recently, most kinds of biofuels were seen as attractive also because they can provide 'drop-in' solutions - they can be distributed through existing infrastructure (pipelines, storage facilities, fuel distribution networks) and end-user technology (internal combustion engines).

From the turn of the century to around 2006/07, government interventions enacted policies that effectively forged the various national and, in the case of the EU, regional foundations of an increasingly global biofuel value chain. The EU and US set minimum mandates on the use of biofuels and provided a range of subsidies, research funding and investment facilities to farmers, processors, blenders, biotech companies and universities. Early Brazilian government support of the 1970s and 1980s had waned by the end of the century, but was revitalized in the 2000s. Agricultural lobbies (US corn, German rapeseed farmers), climate change activists seeking non-fossil fuel alternatives, and government departments concerned with energy and security provided a unique combination of interests that pushed biofuel-friendly policies in a generally favourable political environment (Dauvergne and Neville 2009).

This led to a boost of investments in farming and processing in Brazil, the US and the EU, but also to interest in large-scale investments in land for biofuel production especially in Africa but also in South-east Asia. Following decades of neglect in agricultural and rural development, governments saw large-scale investment in land by domestic and international actors as a welcome boost in infrastructure provision and foreign exchange generation (White and Dasgupta 2010). 
But increasing food prices and the related food riots starting in 2006/07 dramatically altered this picture. Civil society groups started holding biofuel production as a major cause of increasing food prices because it takes land and water away from food production - although estimates of the actual impact of biofuel production on total food price increases vary from 3 to 75 per cent (Smith 2010: 5). Many studies have highlighted deeply problematic aspects of land investments, including shady deals, little benefit for local communities, lack of participation in decision-making at the local level, and environmental degradation (see, among many others, Vermeulen and Cotula 2010; Matondi et al. 2011). Doubts also started to be cast on the impact of biofuel production on GHG emission reductions (Pimentel et al. 2010). Some feedstock-location combinations have been deemed to be especially problematic in terms of GHG balance or in terms of deforestation (for example, ethanol from corn in the US and biodiesel from palm oil in South-east Asia). A wider methodological debate has been raging on how to take into account crop residues and indirect land use change in the calculation of energy balance sheets and GHG emissions (see Smith 2010).

To these arguments, pro-biofuel analysts responded that marginal land is indeed available for biofuel production and that, with modern farm management and improved technology, it is possible to produce a meaningful proportion of fuels for transport from biological resources without affecting food supply (Cortez et al. 2010). Counter-arguments to these highlighted that land is often not actually 'available' even when labeled as such, that in marginal lands yields are much lower, and that faith in technology is misplaced (Levidow and Paul 2010; Smith 2010). 
As criticism mounted on biofuels, the EU enacted demands for sustainability standards for the production, trade and use of biofuels in member countries. The US also fine-tuned its subsidies and regulation to increase support for 'next generation' biofuels (those based on improved and new transformation processes of cellulosic material and other waste, and/or on the development of algae feedstocks) relative to first generation biofuels (those based on the processing of feedstock that can also be used for human consumption). And Brazil increased its public relations effort aimed at showing that sugarcane-based ethanol production in the country has indeed a positive impact on GHG emission reductions (Interviews WBMB2, 19, 20, 38 and 40).

A considerable amount of attention has been paid in the literature to the development of biofuel industries (see, among others, Mol 2007; Dauvergne and Neville 2009; McMichael 2010; Smith 2010; Rosillo-Calle and Johnson 2010; Levidow and Paul 2010; 2011) and of related 'land grabs' and other large-scale investments (especially in Africa) (Vermeulen and Cotula 2010; Matondi et al. 2011). However, much of the existing work focuses on the technicalities of production and feedstock choice, and on projections of the impacts of biofuels on food security, land use and rural livelihoods in developing countries - rather than on analyzing existing investments. Social science work on the role that standards and sustainability certifications are playing in shaping the biofuel industry has just started to appear (Partzsch 2011; Ponte 2013).

Some observers have called this global industry-in-the-making a 'biofuel complex' that is driven by 'a new profitability frontier for agribusiness and energy sectors beset 
with declining productivity and/or rising costs' (Borras et al. 2010: 576) and justified by 'win-win' narratives. Others refer to it as a 'global assemblage' (Smith 2010) or an 'energy-industrial complex' (McMichael 2009). Mol (2007) and Levidow and Paul (2010) call it a 'global integrated biofuel network' (GIBN). In a recent contribution, Altenburg (2011) used the analytical construct of 'value chain' to examine a regional industry (the cultivation of tree-borne oilseeds for biodiesel production in India) and started examining the material and ideational configurations of this value chain in different Indian states. In this article, I further the analytical project of examining the making, governance and increased globalization of the biofuel industry through the lenses of Global Value Chain (GVC) analysis. What kinds of actors are making important decisions shaping the structure of this value chain and its functional division of labour? Are there one or more groups of actors who drive it (if at all)? What are the features of this 'driving'?

In the next section, I provide a brief background on biofuels and discuss case study selection and methodology. In the following section, I briefly review the ongoing debates in the Global Value Chain (GVC) governance literature and main criticisms levied to it in view of highlighting the analytical contribution of this article. In the two main sections of the article, first I examine the formation, evolution and governance of three national/regional value chains (in Brazil, the US and the EU); then I provide evidence support a trend towards the increasing but still partial globalization of the biofuel value chain and examine its governance traits. In the concluding section, I highlight what lessons the biofuel case study teaches us for understanding governance in GVCs. 


\section{Background, case study selection and methodology}

Biofuels are fuels generated by processing specific kinds of biomass, including agricultural crops, for use in transport, electricity production or for domestic uses (heating, cooking). Ethanol accounts for over 90 per cent of biofuel production globally. It is produced by fermenting and distilling sugars from starchy plants (such as sugarcane, sorghum, wheat and corn) into alcohol. So-called 'next generation' ethanols are under development, which are expected to be produced from cellulose contained in forestry products, crop residues and domestic and industrial waste. Ethanol can be used in low percentage mixes in regular engines without modification. Biodiesel is produced from oily crops or trees (such as soya, palm, sunflower and jatropha) and from animal fats and waste cooking oil through the process of transesterification. Some kinds of biodiesel can be used in high-proportion mixes or even unblended in modified diesel engines (see a simplified representation of functions and flows in a generic biofuel value chain in Figure 3). Next generation biodiesel production is expected to use inputs from non-fat biomass through thermo-chemical or biochemical conversion of cellulosic material or other crop residues and waste.

In this article, I focus on three systemically important countries/regions in the biofuel industry: Brazil, the US and the EU. In 2011, they accounted for over $87 \%$ of total production and for $89 \%$ of total consumption of biofuels (see Table 1; Figures 1 and 2). The US and Brazil account for three-quarters of global production of ethanol (mainly from corn in the US and sugarcane in Brazil), with the US and the EU importing substantial amounts (see Table 2). In biodiesel, the EU produces over half of the global volume (mainly from rapeseed in Germany and France), with the US, 
Argentina, Brazil producing around 9\% each (mostly from soy oil) and three Southeast Asian countries providing another $9 \%$ collectively (from palm oil). The EU is the main importer of biodiesel, while Argentina has recently become the main exporter (www.eia.gov and OECD/FAO 2012).

\section{TABLES 1, 2 AND 3; FIGURES 1 AND 2 HERE}

Global biofuel production and consumption have experienced fast growth in the second half of the 2000s, almost doubling from 2007 to 2010 alone (see Table 1), although estimates for future expansion indicate a likely slower pace (OECD/FAO, 2012). Much of the growth in production in this period is accounted by the US, with smaller but significant increases in Brazil and the EU as well. Other fast-growing producing countries, albeit from a lower base, have been Argentina, Indonesia and Thailand. The US increased its share of global production from $42 \%$ in 2007 to $51 \%$ in 2011, while Brazil's share decreased from $36 \%$ to $23 \%$. It is estimated that $65 \%$ of EU vegetable oil, $50 \%$ of Brazilian sugarcane and about $40 \%$ of US corn are currently used for biofuel production (OECD/FAO, 2012: 88). Consumption also increased, almost doubling in the US and the EU, and with substantial growth in Brazil followed by a retreat in 2011 (see Table 1, Figure 3). Consumption growth elsewhere has been less marked. Table 2 shows that biofuel trade was insignificant up to the mid-2000s, while it has accounted for 4-7\% of total production for ethanol in 2005-10 and for 10$18 \%$ for biodiesel in 2007-10. Biofuel trade is expected to grow further at significant rates, driven by differential policies that are likely to lead to ethanol and biodiesel moving to markets where prices are highest (OECD/FAO, 2012: 89). 
The material presented in this article is drawn from secondary sources, semistructured interviews with industry stakeholders and presentations attended at biofuel and bioenergy conferences in Brazil, Denmark, Malaysia, Belgium, the Netherlands and the US from September 2011 to April 2013. ${ }^{1}$ Attending industry conferences is a cost-effective way of carrying out fieldwork aimed at tracing the institutional, regulatory and governance features of a value chain. A wide range of stakeholders attends these conferences -- not only business representatives, but also regulatory agency officials, researchers, civil society actors and the media. Most attendees stay for more than a day, and access to otherwise difficult-to-reach government and corporate representatives is facilitated by network coffee breaks and receptions. While full-fledged interviews may not always be possible at these events, given the busy schedule of top representatives, first contacts allow much easier access for follow-up phone interviews or email correspondence. Following the conference circuit for a period of time also allows repeated interactions, snowball sampling expansion, and the formation of a broader network of contacts with industry actors. The presentations carried out at these conferences are themselves a rich source of information - and are often made available to attendees in the form of power point presentations, sometimes as audio podcasts as well. At the same time, these conferences are sites of 'industry identity formation', where claims may be exaggerated, especially in formal

\footnotetext{
${ }^{1}$ I attended the 'World Biofuels Markets -Brazil' congress and exhibition (Sao Paulo, 28-29 September 2011), the GreenPower Webinar 'Advanced biofuels: Steps to reaching the US EPA target of 20 bn gallons by 2012' (online, 6 October 2012), the 'Copenhagen Cleantech Cluster Annual Conference' (Copenhagen, 11 October 2011), the 'Bioenergy International Asia' expo \& conference (Kuala Lumpur, 7-8 December 2011), the 'ISCC Global Sustainability Conference' (Brussels, 8 February 2012), the 'World Biofuel Markets' congress and exhibition (Rotterdam, 13-15 March 2012), and the Advanced Biofuels Leadership Conference (Washington, DC, 15-17 April 2013).
} 
presentations (on the role of 'buzz creation' in trade fairs, see Bathelt and Schuldt, 2008). This possible bias is, however, less likely to apply in interview settings, especially in follow-up interviews after the event. Triangulation of informationgathering situations and of kinds of actors interviewed provided at least some degree of control against euphoric claims.

During these biofuel-focused conferences, I attended 131 presentations on biofuels (coded $\mathrm{P}$ in the article), delivered by: aviation industry actors (8), biofuel producers, traders and/or refiners (11), biotech/chemical industry representatives (23), certification agencies (7), food and energy industry actors (2), feedstock producers (6), financial institutions (8), industry associations (19), service providers (15), media (4), NGOs (3), regulatory agencies (19) and researchers (6). I also established contacts that led to 78 interviews (face-to-face and/or via email or phone; coded I in the article) with representatives of: aviation industry actors (5), biofuel producers, traders and/or refiners (16), biotech/chemical providers (3), certification agencies or auditors (10), feedstock producers (8), financial institutions (5), industry associations (14), service providers (7), media (1), NGOs (3), regulatory agencies (5), and researchers (1). Interviewees were offered full confidentiality.

\section{The governance of global value chains: A polarity approach}

Since the early 1990s, the Global Value Chain (GVC) literature has sought to understand and explain how the global economy is structured and how it is evolving approaching the 'global' in a 'bottom-up' fashion through aggregation of product- (or 
group of products) specific experiences. In the 2000s, a related literature on Global Production Networks (GPNs) also emerged with similar purposes, partly as a response to the perceived limitations of GVC scholarship. The early GVC literature was generally more structuralist and long-range historical in nature, was focused on common features that made a series of activities look like a chain and developed a dual typology of buyer-driven vs producer-driven governance (Gereffi 1994; Gereffi 1999). The GPN literature has been from the beginning more concerned with the complexity and messiness of these production networks, has given more weight to production processes and technology development, but has had less interest in governance per se (Henderson et al. 2002; Hess and Yeung 2006).

In the past few years, however, the two approaches have overlapped considerably and their common features have become increasingly apparent. In both camps, more attention has been drawn to institutional, regulatory and standard-making processes (Hess and Coe 2006; Coe et al. 2008; Nadvi 2008; Cattaneo et al. 2010; Mayer and Gereffi 2010; Ponte et al. 2011). Both literatures have strived to include in their analyses some of the insights of cultural political economy and to reflect upon differences in business culture (Gibbon and Ponte 2005; Hudson 2008; Bernt and Boekler 2011). The GVC literature has been increasingly fine-tuning the territorial and contested dimensions of restructuring and disarticulation in global value chains (Bair 2009; Neilson and Pritchard 2009; Birch and Cumbers 2010; Bair and Werner 2011; Mahutga 2012) and has also become more nuanced in its 'chain' representations through the analysis of different value chain 'strands' and a variety of governance forms and 'driving' mechanisms (Fold 2002; Islam 2009; Ponte 2009). Each literature has kept highlighting its own specificities, but has moderated its 
critique of the other - to the point that the politics of relative positioning and identity that characterized these literatures in the 2000s is giving way to engaging in actual content and dialogue (Ponte and Sturgeon 2013).

The idea of governance in global value chains rests on the assumption that, while both disintegration of production and its re-integration through inter-firm trade have recognizable dynamics, they do not occur spontaneously, automatically, or even systematically (Gibbon et al. 2008). Instead, these processes arise as a result of strategies and decision-making by specific actors, usually large firms that manage access to final markets. In the original approach to governance developed by Gereffi (1994), governance signals the process of organizing activities with the purpose of achieving a certain functional division of labour along a value chain - resulting in specific allocations of resources and distributions of gains. Here, a group of 'lead firms' drive a value chain through specific mechanisms that are related to the nature of entry barriers and core competences. This involves lead firms defining the terms of chain membership, incorporating/excluding other actors accordingly, generating rents and re-allocating value-adding activities (Gereffi 1994). ${ }^{2}$

In this article, I propose to push the frontier of this approach to governance through the analytical lenses of 'polarity'. Much of the existing GVC literature has focused on 'unipolar' value chains — be they buyer-driven or producer-driven (Gereffi 1994) — where one group of 'lead firms' inhabiting a specific function (or series of functions)

\footnotetext{
${ }^{2}$ Other literature on GVC governance has focused instead on unpacking how coordination takes place at individual links along a GVC (Humphrey and Schmitz 2004; Gereffi et al. 2005) and on the normative elements framing buyer-supplier relations (Gibbon and Ponte 2005; Gibbon et al. 2008).
} 
in a chain play a dominant role in governing it. Some scholars have explored the dynamics of governance in GVCs characterized as 'bipolar' or 'twin-driven', where two sets of actors in different functional positions both drive the chain, albeit in different ways (Fold 2002; Islam 2009). I expand this direction further to suggest examining governance within a continuum between unipolarity and multipolarity.

'Multipolar' chains are different from 'markets' (which, according to neoclassical economics, are not governed), because they are shaped by the explicit strategic actions of powerful actors (both inside and outside the chain), even if they exhibit multiple foci of power and various kinds of linkages. So, while in unipolar chains, overall governance is generally more easily explained on the basis of the dominant governance mechanisms operating in the key node between lead firms and first-tier suppliers, in chains that are bipolar or multipolar, chain dynamics and governing mechanisms are more complex.

A focus on polarity, ranging from unipolar to multipolar governance, allows the construction of different combinations of a plurality of drivers and of driving mechanisms. A plurality of drivers entails that not only firms, but also other actors (such as standard developers, international NGOs, social movements, certification agencies, labour unions and consumer associations) may have a bearing on GVC governance. While these actors have indeed been analyzed as part of the institutional framework surrounding a value chain, they have not been examined as possible 'drivers' or 'governing actors'. 
In the next section, I apply this approach to the case study of biofuels. Instead of looking at only 'lead firms' as governing actors, I expand the analysis to include other relevant actor groups (such as governments) that actively shape the terms of value chain membership, inclusion and exclusion mechanisms, and value creation, appropriation and (re)distribution along biofuel value chains.

\section{National and regional biofuel value chains: Brazil, the US and the EU}

National (Brazil, US) and regional (EU) biofuel industries have existed for decades and have operated fairly independently from each other, indicating that until recently there was a variety of loosely-coupled biofuel value chains, rather than a global one. In this section, I examine the formation, evolution and governance of three national/regional value chains as a stepping-stone for understanding the gradual (and still incomplete) establishment of a global biofuel value chain. Given the space limitations, I will provide a more detailed analysis on Brazil, given its longer biofuel history and pioneering government involvement, while offering briefer comparative perspectives in relation to US and EU biofuel value chains.

\section{Brazil}

Ethanol production in Brazil is hardly a new activity - it goes back as far as the 1920s. However, it became a major factor in Brazil's energy strategy only following the oil crisis of the early 1970s. It was a government programme initiated in 1975 (PROALCOOL) that expanded and governed the Brazilian biofuel value chain 
(IWBM5, 11 and 12). This programme had two components: (1) a target of blending (anhydrous) ethanol in regular gasoline (at a 20-25 per cent of total content); and (2) the promotion of hydrous ethanol (100 per cent ethanol) for use in specially-adapted vehicles (Wilkinson and Herrera 2010). Government intervention included price controls, compulsory supply at fuel stations and subsidies for a range of operations. It had far-reaching effects: by the mid-1980s, ethanol-run cars represented 90 per cent of new car sales, new land was being put into the production of sugarcane for ethanol, most new sugarcane mills had dual-purpose installations (for the production of sugar and ethanol) and the state provided massive investment in research and engineering (on agronomic practices, fermentation processes, machinery) (Presentations PWBMB 1, 2 and 38). In this period, governance of the biofuel value chain in Brazil was unipolar and government-driven. Although the sugar cane and agro-processing industries lobbied for the establishment of such system, it was mainly through government intervention that the chain was governed, with related distribution of functions, incentives and value.

As oil prices dropped in the 1980s, the Brazilian government withdrew some of the subsidies and sugarcane became increasingly used for producing sugar rather than fuel. By 2000, ethanol-only car sales had dropped dramatically and Brazil had to import ethanol. In the past decade, however, with increasing oil prices and the development of flex-fuel models by the auto industry in Brazil, the fortunes of ethanol have started to turn again. Production increased from around 16 bn litres in 2000 to 28 bn in 2010 (McKinsey 2011) and investment in mills saw a major boost. Although government programmes are still important (especially in research and development and in project financing), the Brazilian biofuel (especially ethanol) value chain is now 
becoming more multipolar, with government, the auto industry, ethanol mills and fuel distributors jostling to shape it.

While ethanol production in Brazil is currently competitive with gasoline without major subsidies, the biodiesel industry is still highly dependent on government support (IWBMB4). Brazil has enacted a five per cent obligatory blending of biodiesel under the Brazilian National Biodiesel Program (PNPB). This is accompanied by a 'Social Fuel' certification that enables complying suppliers to participate in the mandatory biodiesel auctions (Wilkinson and Herrera 2010). Thus, the biodiesel component of the value chain is still to a large extent unipolar and government-driven.

Ethanol consumption in Brazil has increased dramatically with the development of the flex-fuel fleet by the auto industry. Flex-fuel cars now account for 44 per cent of the total fleet of light vehicles and in 2010 accounted for 83 per cent of all new vehicle sales (IWBMB3). As long as ethanol price remains under 70 per cent that of gasoline, its demand is expected to increase. However, because sugar prices increased dramatically in the past few years (only to fall again more recently), Brazilian industry actors, with government support, have also been looking into creating supply abroad to import ethanol for this growing demand (IWBMB11) thus creating some of the foundations for the increasing globalization of the value chain (see below).

A key governmental role in the governance of the biofuel value chain in Brazil is still played by the national development bank (BNDES). BNDES has a large portfolio of investment and a special department dedicated to biofuel investments. Its agenda is to 
expand industry capacity, finance logistics improvements for efficient ethanol transportation, finance the capital goods supply chain and finance innovation (including the development advanced platforms that can produce a variety of final products). Total disbursement for biofuel investments over the $2008-10$ period has been a staggering $\mathrm{R} \$ 11.1 \mathrm{bn}$ (or US\$ $4.3 \mathrm{bn}$ ). BNDES finance for investment in ethanol production more than doubled from 2007 ( $\mathrm{R} \$ 1.7 \mathrm{bn})$ to 2010 ( $\mathrm{R} \$ 3.6 \mathrm{bn})$ (McKinsey 2011). However, this has not been enough to keep up with the development of demand, and Brazil in the first eight months of 2011 had to import more than 600 million litres of ethanol (against a historical average of less than 10 million) (Ibid). BNDES is also contributing to the increasing globalization of the Brazilian biofuel industry through support for investments abroad, especially in Africa (IWBMB3).

Following the start of the current financial and economic crisis, greenfield investment has slowed down in ethanol processing in Brazil, and many mills facing financial woes have been bought up by major existing players (Cosan) and relatively new and increasingly important ones (Petrobras, Bunge, Noble Group) (IWBMB4 and 6). New uses for ethanol are also being developed - especially for the production of stationary electricity and bioplastics, adding complexity to its features (various WBMB presentations). Expectations in the industry are of further consolidation. As stated by one industry player 'in the near future, four-five large players with capacity of crushing 100 or more million tons of cane per year will be leading the industry’ (IWBMB5). Table 3 indicates that foreign (BP, Noble, Bunge) or joint venture groups (Cosan/Raizen) accounted for 13 of a total 31 mill-level M\&A operations in 20092011, a largely new phenomenon. Noticeable is also the novel role played by 
government-controlled Petrobras (it acquired nine mills). A large share of total production in 2015 is expected to come from large mills (McKinsey 2011).

In addition to increased consolidation, new functional divisions of labour are emerging along the value chain, with partial vertical integration or strategic alliances taking place between milling and international trading, and between milling and refining/fuel distribution (IWBMB11). Cosan and Shell have formed a $\$ 12$ billion joint-venture called Raizen to produce and commercialize bioethanol and electricity from sugar cane and distribute a variety of fuels through a combined distribution and retail network in Brazil. It is also seeking opportunities to produce and sell ethanol and sugar globally (PWBMB35). According to an industry player 'Cosan needs downstream integration in distribution where the main proportion of value added is created. Shell needs bioethanol as petrol availability decreases in the long term' (IWBMB5). Other international trading houses, sugar producers and agro-chemical companies have also started (or expressed interest in) investments in the sector. For example, Crystalsev, one of the largest Brazilian ethanol distributors and marketers, has started a bioplastics operation with Dow Chemical (Wilkinson and Herrera 2010) and collaborates with Amyris on biodiesel (PWBMB5). Odebrecht (the largest engineering and construction company in Brazil) is also investing in the biofuels sector. Vale (the largest Brazilian mining group) has established a subsidiary (with co-financing from BNDES) to develop power generation technologies, equipment and systems, including biofuels (IWBMB12). Vale has also entered into an agreement with Bunge to ship ethanol through the Brazilian North-South railway and is said to be interested in expanding its biofuel-related interests in Africa as well (IWBMB3). 
Biorefineries that process corn into ethanol have been operational for decades in the US. Originally, most of these were local, part of farmer cooperatives and with limited corporate involvement. By and large, before the 2000s, the biofuel value chain in the US was a loose assemblage of localized value chains, as the industry was fragmented and only weakly integrated (IWBMB1). In these conditions, there was little explicit governance of the value chain. In the 2000s, however, rising oil prices and political instability in the oil-rich Middle East facilitated the emergence of a policy discourse in the US that made biofuel production more attractive (Gillon 2010; Lehrer 2010). The 2002 US Farm Bill for the first time included an energy sub-section with provisions for federal procurement of biofuels, and grants and subsidized loans for farmers. Most importantly, the 2005 Energy Bill introduced a renewable fuels mandate to produce 7.5 billion gallons of fuel from renewable resources by 2012 . This led to dramatic increases in corn acreage (to record levels) and in the number and capacity of biorefineries (Gillon 2010), but also to the entry of large agro-food corporations in the sector. The 2007 Energy Bill ramped up such target to 36 billion gallons by 2022 (Lehrer 2010). As farm bill interest groups and sustainable agriculture lobbies increasingly focused on biofuels, the 2008 Farm Bill included provisions for biofuel tax credits for producers and blenders (IWBMB1) and incentives for feedstock research and for the construction of 'next generation' biofuel production facilities (Lehrer 2010).

In other words, a national biofuel value chain in the US was essentially forged by government in the 2000s (through lobbying efforts of agricultural and agro-processing 
industries) and mostly shaped by policy intervention. However, starting in 2007/08, the backlash against biofuels from environmental and social NGOs eventually led the Obama administration in early 2010 to recalibrate its targets (Biofuel Digest 12/5/2011). In parallel to this process, major private sector players (ADM, DuPont, Monsanto) established the 'Alliance for Abundant Food and Energy' to further promote biofuels with the US government in ways that decouple them from foodrelated concerns (Dauvergne and Neville 2009: 1099). This slightly revised policy discourse configuration on biofuels in the US has provided stronger ground for the multiplication of 'next generation' biofuel technology development, with a strong cluster emerging in California (various presentations at WBM, BICA, WBMB, ABLC conferences).

Biofuel producers have been operating for decades in selected EU countries as well. But it was only in the 2000s that a large boost was provided to the industry when individual governments within the EU first started adopting mandatory targets for use of biofuels in transport. Governments and later on the EU Commission became more open to policy influence from farm interests (especially from rapeseed and sugar beet producers) and corporate lobbyists (IWBM11 and 17; see also Franco et al. 2010). They also started promoting biofuel investments in Africa and South-east Asia via technical assistance, energy supply deals and the facilitation of land acquisitions (IBICA1, 2 and 9). At the EU level, the European Biofuel Technology Platform (EBPTF) which steering committee is packed with actors from farm, oil, auto, biotech, biofuel and forestry products industries, has been very active in shaping policy (Franco et al. 2010). 
The most important output of the EU policy process was the establishment of the 2009 Renewable Energy Directive (RED), requiring 20 per cent of energy use in the EU and 10 per cent of transport fuels to come from renewable sources by 2020. Because there is not enough land available in the EU to produce the first generation biofuel feedstocks necessary for this target, the original EU directive was in effect stimulating two parallel processes: the outsourcing of biofuel production outside the EU; and a speeding up of development, commercialization and scaling-up of 'next generation' biofuel technologies.

Partly in response to mounting environmental criticism of biofuel production, in June 2010 the Commission adopted a scheme for certifying sustainable biofuels. In order to receive government support or count towards mandatory national renewable energy targets, biofuels used in the EU (whether locally produced or imported) have to comply with sustainability criteria including: land use (no conversion of land with high carbon stock or land with high biodiversity value); a minimum reduction of GHG emissions over the whole production chain ( 35 per cent less than gasoline); ${ }^{3}$ and a system monitoring the whole value chain from feedstock to the pump (PISCC62, 63, 65). The Commission decided to set up an accreditation system for voluntary certification schemes that meet its criteria. This has led to a veritable scramble in the market for sustainability certifications. In July 2011, the EU recognized a first batch

\footnotetext{
${ }^{3}$ From 2017, GHG emission reductions will need to rise to 50 per cent for existing production and 60 per cent for new installations.
} 
of seven certifications, followed by six more certifications in the second half of 2012 (see details in Ponte 2013). ${ }^{4}$

In this section, I have shown that the biofuel value chain in Brazil evolved, since the 1970s, from a government-driven unipolar chain to a multipolar chain where government action is still influential, but where major agro-industrial groups, ethanol producers, agro-chemical and bio-tech companies jostle to govern it. I have also highlighted that national/regional biofuel value chains emerged in the US and the EU, but mostly in the 2000s. They were first characterized by unipolar governance structures, led by government, but are now also developing into multipolar value chains. A common trend in the US and the EU is the emerging powerful role of the biotech industry at the expense of the traditional farming lobby. In the next section, first I provide evidence to support a trend towards the increasing but still partial globalization of the biofuel value chain. Then, I examine its governance traits.

\section{The emergence of an increasingly global biofuel value chain and its governance}

The biofuel value chain is becoming increasingly global through a variety of processes of internationalization, cross-regionalization and a few properly 'global' dynamics. Although a precise measurement of 'globalization' is not possible in

\footnotetext{
${ }^{4}$ In October 2012, the European Commission released a proposal for a directive that would make significant changes to its biofuel policies. If adopted in its present form, the proposal would leave only small room for expansion for traditional biofuel feedstocks in the near future, while stimulating the emergence of a new captive market for next-generation biofuels.
} 
succinct quantitative terms, a combination of three elements clearly signals a trend in that direction: (1) increased trade flows and broader geographic dispersion of feedstock production; (2) new international and cross-regional processes taking place mostly through government-led or -facilitated initiatives; and (3) increasing consolidation among industry actors, the rise of international operations and alliances, and the increased and sometimes completely new involvement of global players from the agro-food, fuels and agro-processing industries in biofuels.

First, as examined in an earlier section of this article, substantial trade flows in biofuels that were not present in the early 2000s not only have emerged (see Table 2), but are also becoming more geographically complex (see Lamers et al. 2011 for a graphic representation of this trend in time). A geographic expansion of feedstock production is taking place as well, with the emergence of new producers such as Argentina, Indonesia and Thailand.

Second, new forms of international and cross-regional cooperation are taking place. These were all developed in the second half of the 2000s. Partly as a response to the backlash against the biofuel industry, Brazil and the US have set aside their historical competitive streak in biofuels and started to collaborate in the context of a hemispheric project involving alliances with Central American actors and institutions (specifically, CAFTA member countries) (Hollander 2010). During President Bush's trip to Latin America in 2006 an 'Ethanol Agreement' was signed between Brazil and the US to share technology for enhancing ethanol production. The agreement, which main purpose was to develop the international ethanol market and the infrastructure needed to support production, distribution and consumption, was supported by 
agribusiness firms (domestic and multinational), central and local governments in both countries, and trade and industry associations (ibid.).

Other novel international and cross-regional processes are taking place along the Brazil-Africa axis. Brazil has signed bilateral cooperation agreements with Angola and Mozambique that include cooperation on sugarcane and ethanol production and has opened a research station in Ghana with the purpose of helping replicate the Brazilian 'sugarcane ethanol model' in the continent through the transfer of breeding science, plantation management methods and processing technology (IWBMB3, 11 and 12; see also Richardson 2010; Wilkinson and Herrera 2010) In Angola, a joint venture between a major Brazilian engineering firm (Oderbrecht), state-owned oil company Sonangol and a private Angolan firm (Damer) is establishing a sugarcane plantation for bioethanol production (IWBMB11 and 12; see also Richardson 2010; Smith 2010). In 2007, Mozambique and Brazil agreed to share resources in biofuel production (Franco et al 2010; Buur et al. 2011) and in 2009 they signed two agreements for investment in biofuel production for export to Brazil (Smith 2010). Brazil is explicitly seeking to develop ethanol supply abroad to forge a global market for biofuels (IWBMB3 and 5). This approach includes helping to develop agriculture in Africa through technical assistance, equipment provision, financing and support for logistics and distribution.

Third, new international alliances in the private sector and an increasingly complex web of cross-regional investments are emerging. Although a complete dataset of biofuel-related investments over time is not available, virtually all relevant industry players interviewed indicated that the size, number and geographical spread of 
international joint ventures has increased dramatically in the past decade, and that the involvement of global agro-food traders, oil majors, auto and aircraft manufacturers and the aviation industry is either new or has heightened substantially. ${ }^{5}$

A large majority of presentations at the conferences I attended were actually a showcase for a variety of international joint ventures or collaborations that had global ambitions. Although some of the claims on ambition may have been exaggerated, they did involve a disparate combinations of interests in the automobile, aviation, biotechnology and energy industries. For example, Renessen (a joint venture of Cargill and Monsanto) aims at integrating animal feed and biofuel production where the feedstock can be used for both purposes (Borras et al 2010: 577). It has also developed a dedicated GM corn crop with higher oil content (White and Dasgupta 2010: 604). Monsanto and Syngenta have recently developed GM maize varieties specifically for processing into ethanol. Cosan and Shell have formed a large joint venture in Brazil that is investing heavily in the country and exploring international investments are well (IWBMB6). British Airways and Solena Biofuels recently announced a joint-venture to produce aviation biofuels from waste by 2015 (IABLC27; PALBC116). European, Indian, Korean, Singaporean and Malaysian biofuel investments are either on the table or are being carried out in Africa and

\footnotetext{
${ }^{5}$ A database of biofuel investments made in 2009 compiled by Biofuel Digest lists 81 projects for a total value of US\$ $8.7 \mathrm{bn}$. Roughly three-quarters of these projects were based in OECD countries but accounted for only $36 \%$ in value terms. The database, however, is not complete and is biased in favour of reporting US-based investments. A newer, equally problematic, database includes projects up to the $3^{\text {rd }}$ quarter of 2012 and shows a roughly similar geographical spread between OECD countries and the rest of the world, but does not report investment values. Therefore a comparison in time is not possible in reliable terms. See http://www.biofuelsdigest.com/bdigest/biofuels-digest-superdata/
} 
South-east Asia (IBICA2, 5 and 9; WBM2 and 4). Many others, however, have folded (see Havnevik and Haaland 2011 for an example).

The increasingly global reach of the biofuel value chain is also indicated by the involvement of 'global players' that are new to the industry or that previously played only a marginal role. Several global agri-food traders (Bunge, Noble Group, ADM and LouisDreyfus, to a less extent ED\&F Man) have developed major interests in biofuels, while Cargill is establishing 'biofuel support services' (IISCC1, 2, 3, 5, 7 and 8; WBM1 and 15; IALBC9). These processes are often leading to increased vertical integration in the industry. Part of the motivation towards vertical integration is to ensure supply and control costs to maximize returns; part is to ensure control of processes and sources of supply of certified 'sustainable biofuels' for the European market (IISCC1, 3 and 7; WMB1, 4 and 15). Major oil companies are also investing in biofuel research (Chevron, ExxonMobil, Shell are all financing major university research facilities) (Smith 2011), in ethanol production facilities and/or in integrated distribution of fuels (Shell-Cosan, Petrobras, BP) (IWBM15 and ISSC8; various IALBC). Aircraft manufacturers (Boeing, Airbus and Embraer), major global airlines (Lufthansa, KLM-Air France, British Airways and several US airlines) and the US Navy are carrying out pilot projects for the production of 'drop-in' biofuels for aviation (various presentations at WBMB, ISCC, WBM and ABLC conferences). Developers of GM crops (Syngenta, Monsanto, DuPont, Dow, Bayer and BASF) are working on feedstocks dedicated to biofuels, also through cooperation agreements with global agro-food traders. Venture capital companies are bankrolling the biotech boom in platform technologies and synthetic biology, and some of these start-ups are being bought up by oil and agro-chemical giants (various presentations at WBMB, 
WBM and ABLC conferences). CGIAR and global philanthropies (the Gates Foundation) are funding major research initiatives.

All these indicators suggest that national and regional biofuels value chains are merging into a nascent global value chain. The biofuel conference circuit itself is a tool of global identity formation for the industry. Even at conferences with a clear regional focus, most presentations on national and regional trends I attended were placed in the context of the emergence of a global industry, the involvement of global players and the rise of global challenges. Yet, this globalization process is still partial. Much biofuel consumption and production is still concentrated in the Brazil, the US and the EU. International trade flows as proportion of total production are smaller than those of other major agro-food commodities, especially for ethanol. And biofuel industries are still to an important extent governed by national and regional regulatory and policy processes.

As we have seen in the previous section, national and regional biofuel value chains in Brazil, the US and the EU, until the mid-2000s were characterized by unipolar, and mostly government-driven, governance through minimum mandates, tariff protection, investment incentives and subsidy provision to farmers and processors. This is not necessarily a feature of national and regional value chains per se (vis a vis global value chains), but rather an empirical observation. Figure 3 shows that these value chains were unipolar (polarity is represented by the number of ovals) and that the main 'driver' was government (the oval encompasses the whole value chain as government shapes most if not all its constituent elements). In this configuration, industry actors exert influence mainly through lobbying government, rather than 
impacting on other value chain actors directly. A more traditional kind of GVC governance analysis would have focused on identifying one (or two) groups of 'lead firms' located at one or more functional positions in the value chain, while the role of government would have been relegated to the institutional framework surrounding the value chain.

\section{FIGURES 3 AND 4 HERE}

In contrast, the nascent global biofuel value chain can be characterized in Figure 4 as multipolar (with a multitude of ovals). An important governing role still played by government, but also by other indirect actors (such as sustainability standards makers and certifiers, environmental and social NGOs; see outer oval) ${ }^{6}$ and by an emerging group of direct value chain actors that operate at different functional positions in the chain: providers of inputs and technology (global agro-chemical and biotech companies), producers/international traders (of feedstocks and biofuels), oil majors/distribution companies, and providers of end-use technology (airlines, aircraft and engine manufacturers, auto manufacturers). ${ }^{7}$ It is the interplay of this complex constellation of actors that will determine the future shape of the biofuel industry and related (re)distributional effects.

\footnotetext{
${ }^{6}$ Due to lack of space, an analysis of the increasing role of civil society groups, international NGOs and standard and certification agencies in governing the biofuel value chain cannot be presented here. However, details of this process can be found in Ponte (2013).

${ }^{7}$ This is obviously a simplified representation, as it does not reflect that public institutions and private companies are engaging in extensive R\&D activities, or in supporting them, and that financial institutions (venture capital, institutional investors and banks) are also playing a key role in expanding investment.
} 


\section{Conclusion}

The case study of biofuels provides three main insights for furthering the understanding of governance in global value chains. First, it suggests that examining the evolutionary paths of value chain governance is essential. This involves tracing changing structures and configurations (and policy discourses underpinning them) in time, but also analyzing the national and regional bases upon which global industries are built. The case study of biofuels shows how government intervention and support led to clear processes of consolidation in national and regional biofuel value chains that ultimately provided a springboard for the internationalization and crossregionalization of investment and the engagement of truly global players in the industry. Examining how national and regional dynamics are extended to forge global value chains is thus essential in understanding their governance.

Second, the biofuel case study suggests that a focus on 'lead firms' in GVC governance is not sufficient. Without government mandates, subsidies and bankrolling of research, this industry would not exist. Without regulation demanding 'sustainability', the market for certified biofuels would have been much smaller or even non-existent. At least in their formative phase, biofuel value chains were 'government-driven' in the sense that regulatory choices directly shaped their structure and functional division of labour. Granted, a variety of lobbies were behind the policy processes that led to regulation, but these can not be ascribed to one segment of the industry alone. As the biofuel value chain becomes more global, a new set of key global drivers is emerging, including direct value chain actors such as providers of inputs and technology, producers and international traders, oil majors and 
distribution companies, and providers of end-use technology, but also indirect players such as sustainability standards makers and certifiers, social movements and international NGOs.

Third, much of the GVC literature has so far focused on 'unipolar' value chains chains that are driven by one set of actors carrying out a specific function or a group of functions along a value chain (e.g. buyer-driven, producer-driven chains). Some scholars have ventured into the analysis of 'bipolar' chains, where two groups of actors jostle to get the upper hand in governing. I argue that it is helpful to expand this direction further to examine governance in relation to a continuum between unipolarity and multipolarity. Multipolar chains are not just 'markets' (non-governed, as neoclassical economics would have it), but are shaped by explicit strategic actions, by various kinds and degrees of coordination and exhibit multiple foci of power. From this perspective, the global biofuel value chain is becoming multipolar and driven by several groups of lead firms in complex interaction with governments, standard makers and international NGOs. These actors are currently competing over creating or allocating new value, extracting value from others and re-defining the functional division of labour along the chain. It is still early to assess whether the global biofuel value chain will develop a unipolar (or bipolar) governance structure with 'lead firms' playing a predominant role (as is the case in many other industries). But examining the evolutionary dynamics of governance along these axes should be part of future research in this industry and in others.

Acknowledgements. The author is grateful to the journal's editors, three referees and Kean Birch for useful and constructive comments on earlier versions of this article. 
He would also like to acknowledge key feedback obtained at the workshop "Value Chains, Production Networks, and the Geographies of Development: Emerging

Challenges and Future Agenda", National University of Singapore (1-2 December 2011) and at the 2012 convention of the Association of American Geographers (AAG) in New York.

\section{References}

Altenburg, T. (2011) 'Interest groups, power relations, and the configuration of value chains: The case of biodiesel in India', Food Policy, 36: 742-748.

Bair, J. (ed.) (2009) Frontiers of Commodity Chain Research, Stanford: Stanford University Press.

Bair, J. and Werner, M. (2011) 'Commodity chains and the uneven geographies of global capitalism: A disarticulations perspective', Environment and Planning A, 43: 988-997.

Bathelt, H. and Schuldt, N. (2008) 'Between luminaires and meat grinders: International trade fairs as temporary clusters', Regional Studies 42(6): 85368.

Bathelt, H. and Spigel, B. (2012) 'The spatial economy of North American trade fairs', The Canadian Geographer 56(1): 18-38.

Berndt, C. and Boeckler, M. (2011) 'Performative regional (dis)integation: Transnational markets, mobile commodities, and bordered North-South differences', Environment and Planning A, 43: 1057-1078. 
Birch, K. and Cumbers, A. (2010) 'Knowledge, space and economic governance: The implications of knowledge-based commodity chains for less-favoured regions', Environment and Planning A, 42: 2581 - 2601.

Borras, S.M. Jr, McMichael, P. and Scoones, I (2010) 'The politics of biofuels, land and agrarian change: Editors' introduction', Journal of Peasant Studies, 37(4): $575-592$.

Buur, L., Mondlane, C. and Baloi, O. (2011) 'Strategic privatization: Rehabilitating the Mozambican sugar industry', Review of African Political Economy, 38(128): 235-256

Cattaneo, O., Gereffi, G. and Staritz, C. (eds) (2010) Global Value Chains in a Postcrisis World: A Development Perspective, Washington, DC: World Bank.

Coe, N., Dicken, P. and Hess, M. (2008) 'Global production networks: Realizing the potential', Journal of Economic Geography, 8: 271-295.

Cortez, L. and Regis, M. with Sinkala, T. (2010) 'Why biofuels are important', in . Rosillo-Calle and F.X. Johnson (eds.), Food versus Fuel: An Informed Introduction to Biofuels, London: Zed Books, pp. 59-85.

Dauvergne, P. and Neville, K.J. (2009) 'The changing North-South and South-South political economy of biofuels', Third World Quarterly, 30(6): 1087-1102.

Fold, N. (2002) 'Lead firms and competition in 'bi-polar' commodity chains: Grinders and branders in the global cocoa-chocolate industry', Journal of Agrarian Change, 2(2): 228-47.

Franco, J., Levidow, L., Fig, D., Goldfarb, L., Hönicke, M. and Mendonça, M.L. (2010) 'Assumptions in the European Union biofuels policy: Frictions with 
experiences in Germany, Brazil and Mozambique', Journal of Peasant Studies, 37(4): 661-698.

Gereffi, G. (1994) 'The organization of buyer-driven global commodity chains: How us retailers shape overseas production networks', in G. Gereffi and M. Korzeniewicz (eds.) Commodity Chains and Global Capitalism. Westport: Greenwood Press, pp. 95-133.

Gereffi, G. (1999) 'International trade and industrial up-grading in the apparel commodity chain', Journal of International Economics, 48(1), 37-70.

Gereffi, G., Humphrey, J. and Sturgeon, T. (2005), 'The governance of global value chains', Review of International Political Economy, 12(1): 78-104.

Gibbon, P. and Ponte, S. (2005) Trading Down: Africa, Value Chains and the Global Economy, Philadelphia: Temple University Press.

Gibbon, P., Bair, J. and Ponte, S. (2008) 'Governing global value chains: An introduction', Economy and Society, 37(3): 315-338.

Gillon, S. (2010) 'Fields of dreams: Negotiating an ethanol agenda in the Midwest United States', Journal of Peasant Studies, 37(4):723-748.

Havnevik, K. and Haaland, H. (2010) 'Biofuel, land and environmental issues: The case of SEKAB's biofuel plans in Tanzania', in P. Matondi, K. Havnevik and A. Beyene (eds.) (2011) Biofuels, Land Grabbing and Food Security in Africa, London and Uppsala: Zed Books and Nordic Africa Institute, pp. 106-133.

Henderson J., Dicken, P., Hess, M., Coe, N., and Yeung, H.W-C. (2002) 'Global production networks and the analysis of economic development', Review of International Political Economy, 9(3): 436-464. 
Hess, M. and Coe, N.M. (2006) 'Making connections: global production networks, standards, and embeddedness in the mobile-telecommunications industry', Environment and Planning A, 38: 1205-1227.

Hess, M. and Yeung H. W-C. (2006) 'Whither Global Production Networks in economic geography? Past, present and future', Environment and Planning A, 38: 1193-1204.

Hollander, G. (2010) 'Power is sweet: Sugarcane in the global ethanol assemblage', Journal of Peasant Studies, 37(4): 699-721.

Hudson, R. (2008) 'Cultural political economy meets global production networks: A productive meeting?', Journal of Economic Geography, 8: 421-440.

Humphrey, J. and Schmitz, H. (2004) 'Chain governance and upgrading: taking stock', in H. Schmitz (ed.) Local Enterprises in the Global Economy: Issues of Governance and Upgrading, Cheltenham: Edward Elgar, pp. 349-382.

Islam, M.S. (2009) 'From pond to plate: Towards a twin-driven commodity chain in Bangladesh shrimp aquaculture', Food Policy, 33: 209-223.

Lamers, P. (2011) 'International biodiesel markets: Developments in production and trade', Berlin: UFOP.

Lamers, P., Hamelinck, C., Junginger, M. and Faaij, A. (2011) 'International bioenergy trade: A review of past developments in the liquid biofuel market', Renewable and Sustainable Energy Reviews, 15: 2655-2676.

Lehrer, N. (2010) '(Bio)fueling farm policy: The biofuels boom and the 2008 Farm Bill', Agriculture and Human Values, 27: 427-444. 
Levidow, L. and Paul, H. (2010) 'Global agrofuel crops as contested sustainability, Part I: Sustaining what development?' Capitalism, Nature, Socialism, 21(2): 64-86.

Levidow, L. and Paul, H. (2011) 'Global agrofuel crops as contested sustainability, Part II: Eco-efficient techno-fixes? ' Capitalism, Nature, Socialism, 22(2): 2751.

Mahutga, M.C. (2012) 'When do value chains go global? A theory of the spatialization of global value chains', Global Networks, 12(1): 1-21.

Matondi, P., Havnevik, K. and Beyene, A. (eds.) (2011) Biofuels, Land Grabbing and Food Security in Africa, London and Uppsala: Zed Books and Nordic Africa Institute.

Mayer, F. and G. Gereffi (2010) 'Regulation and economic globalization: Prospects and limits of private governance', Business and Politics, 12(3), Article 11.

McKinsey (2011) ‘Ensuring Brazil's Enduring Leadership in the Global BioEconomy', Rio de Janeiro: McKinsey.

McMichael, P. (2010) 'Agrofuels and in the food regime', Journal of Peasant Studies, 37(4): 609-629.

Mol, A.P.J. (2007) 'Boundless biofuels? between environmental sustainability and vulnerability', Sociologia Ruralis, 47(4): 297-315.

Nadvi, K. (2008) 'Global standards, global governance and the organization of global value chains', Journal of Economic Geography, 8: 323-343. 
Neilson, J. and Pritchard, B. (2009) Value Chain Struggles: Institutions and Governance in the Plantation Districts of South India, Malden, MA and Oxford: Wiley-Blackwell.

OECD/FAO (2011) 'OECD-FAO Agricultural Outlook 2011-2020', OECD and FAO: Paris and Rome.

OECD/FAO (2012) 'OECD-FAO Agricultural Outlook 2012-2021', OECD and FAO: Paris and Rome.

Partzsch, L. (2011) 'The legitimacy of biofuel certification', Agriculture and Human Values, 28: 413-425.

Pimentel, D., Marklein, A., Toth, M.A., Karpoff, M.N., Paul, G.S., McCormack, R., Kyriazis, J., and Krueger, T. (2010) 'Why we should not be using biofuels', in F. Rosillo-Calle and F.X. Johnson (eds.), Food versus Fuel: An Informed Introduction to Biofuels, London: Zed Books, pp. 29-57.

Ponte, S. (2013) “"Roundtabling” sustainability: Lessons from the biofuel industry', Geoforum, under review.

Ponte, S. (2009) 'Governing through quality: Conventions and supply relations in the value chain for South African wine', Sociologia Ruralis, 39(3): 236-257.

Ponte, S. and Gibbon, P. (2005) 'Quality standards, conventions and the governance of global value chains', Economy and Society, 34(1): 1- 31.

Ponte, S., Gibbon, P. and Vestergaard, J. (eds.) (2011) Governing through Standards: Origins, Drivers and Limitations. Basingstoke and New York: Palgrave Macmillan. 
Ponte, S. and Sturgeon, T. (2013) 'Explaining Governance in Global Value Chains: A Modular Theory-building Effort', Review of International Political Economy, forthcoming.

Richardson, B. (2010) 'Big Sugar in southern Africa: Rural development and the perverted potential of sugar/ethanol exports', Journal of Peasant Studies, 37(4): 917-938.

Rosillo-Calle, F. and Johnson, F.X. (eds.) (2010) Food versus Fuel: An Informed Introduction to Biofuels, London: Zed Books.

Smith, J. (2010) Biofuels and the Globalization of Risk: The Biggest Change in NorthSouth Relationships since Colonialism? London: Zed Books.

Sturgeon, T. (2009) 'From commodity chains to value chains: Interdisciplinary theory building in an age of globalization', in J. Bair (ed.) Frontiers of Commodity Chain Research, Stanford: Stanford University Press, pp. 110-135.

Vermeulen, S. and L. Cotula (2010) 'Over the heads of local people: Consultation, consent, and recompense in large-scale land deals for biofuels projects in Africa, Journal of Peasant Studies, 37(4): 899-916.

White, B. and Dasgupta, A. (2010) 'Agrofuels Ccpitalism: A view from political economy', Journal of Peasant Studies, 37(4): 593-607.

Wilkinson, J. and Herrera, S. (2010) 'Biofuels in Brazil: Debates and impacts', Journal of Peasant Studies, 37(4): 749-768. 